\title{
Ecology of Mabuya agilis (Raddi) (Lacertilia, Scincidae) at the restinga of Grumari, Rio de Janeiro, southeastern Brazil
}

\author{
Davor Vrcibradic ${ }^{1,2}$ \\ Carlos Frederico Duarte Rocha ${ }^{1}$
}

\begin{abstract}
Some aspects of the ecology of the skink Mabuya agilis (Raddi, 1823) at the restinga habitat of Grumari, in Rio de Janeiro, Brazil are studied. Most of the lizards were first sighted on the ground, though a few were using perches (mainly cacti) up to $30 \mathrm{~cm}$ high. Mean body temperature in activity was $33.1 \pm 2.4^{\circ} \mathrm{C}$ and was significantly correlated to air temperature. There was sexual dimorphism in size (snout-vent length - SVL), with females growing larger than males. Frequency of broken tails was high overall ( $83 \%)$ and did not differ between sexes. Females and males are sexually mature at $49 \mathrm{~mm}$ and $47 \mathrm{~mm}$ SVL, respectively. Brood size averaged $3.2 \pm 1.0$ (range 1-5) and was positively and significantly related to female SVL $(r=0.65, p=0.001)$. Relative clutch mass (RCM) of seven gravid females averaged $0.250 \pm 0.042$, being relatively low compared to those of other congeners. The diet of M. agilis was composed basically of arthropods, with relatively large and soft-bodied arthropods such as spiders, caterpillars and homopterans being the most important prey. The results of our work confirm and expand the knowledge of ecological tendencies previously observed for M. agilis in other areas.

KEY WORDS. Mabuya agilis, lizard, thermal ecology, diet, reproductive traits, restinga habitat, southeastern Brazil
\end{abstract}

The knowledge on the ecology of lizard species along the coast of Brazil has increased after the studies developed during the last two decades which have interestingly improved our knowledge on some ecological parameters of lizard populations (see reviews in ROCHA 1994 and ROCHA et al. 2000). However, it is also important to accumulate information on various populations of a particular species in different areas, which can allow us to understand to which extent ecology can vary along its geographical range and how ecological parameters can change under different environmental conditions (e.g. PIANKA 1970; VITT \& COLLI 1994; ROCHA et al. 2002b).

The skink Mabuya agilis occurs continuously along much of the southeastern Brazilian coast, from Rio de Janeiro to southern Bahia, being quite common in "restinga" habitats (ROCHA \& BERGALLO 1997; ROCHA 2000). In some coastal areas along that species' range, some studies have recently been carried out on various aspects of its ecology, including thermal ecology (ROCHA \& VRCIBRADIC 1996; VRCIBRADIC \& ROCHA 2002), reproduction (ROCHA \& VRCIBRADIC 1999; ROCHA

1) Setor de Ecologia, DBAV, Instituto de Biologia, Universidade do Estado do Rio de Janeiro. Rua São Francisco Xavier 524, 20550-013 Rio de Janeiro, Rio de Janeiro, Brasil.

2) Corresponding author: Pós-Graduação em Ecologia, Departamento de Zoologia, Instituto de Biologia, Universidade Estadual de Campinas. Caixa Postal 6109, 13081-970 Campinas, São Paulo, Brasil. E-mail: vdavor@uol.com.br 
et al. 2002b) and other general ecological aspects (VRCIBRADIC \& ROCHA 1995, 1996; ROCHA et al. 2002a). The more the ecology of this species can be studied along different portions of its range, the more we can understand the range of variation of its ecological responses to the differences in habitat characteristics.

In the present work we study some aspects of the ecology of $M$. agilis in an area close to the southernmost limit of occurrence of that species (Grumari, Rio de Janeiro state, Brazil) and compare our results with the data available on ecological parameters for conspecific populations in other areas.

\section{MATERIAL AND METHODS}

\section{Study Area}

Fieldwork was carried out at the restinga habitat of Grumari $\left(23^{\circ} 03^{\prime} \mathrm{S}, 43^{\circ}\right.$ 32 'W), in Rio de Janeiro municipality, Rio de Janeiro State, Brazil. Restinga habitats are characterized by sandy soil covered with grassy-herb and scrub vegetation, and are part of the Atlantic rainforest biome (SUGUIO \& TESSLER 1984; EITEN 1992). The Grumari restinga is characterized by a relatively dense vegetation cover (i.e. low proportion of clearings) compared to other restingas of southeastern Brazil (see ROCHA \& BERGALLO 1997). The vegetation is predominantly arbustive and herbaceous, with a few larger trees; cacti (mainly Cereus fernambucensis Lem. and Pilosocereus arrabidae (Lem.) Byles \& Rowley), bromeliads (mainly Quesnelia quesneliana (Brongn.) L.B. Smith, Vriesea neoglutinosa Mez and Neoregelia sarmentosa (Regel) L.B. Smith) and the dwarf sand palm or Guriri (Allagoptera arenaria (Gomes) Kuntze) are relatively abundant. The area of Grumari is close to the southern limit of distribution of $M$. agilis (ca. $23^{\circ} \mathrm{S}$, see VANZOLINI 1988). Other lizards occurring sympatrically with $M$. agilis at this area are Ameiva ameiva (Linnaeus, 1758) and Tupinambis merianae (Duméril \& Bibron, 1839) (Teiidae), Tropidurus torquatus (Wied, 1820) and Liolaemus lutzae Mertens, 1938 (Tropiduridae), Gymnodactylus darwini (Gray, 1845) and Hemidactylus mabouia (Moreau de Jonnés, 1818) (Gekkonidae), and Mabuya macrorhyncha Hoge, 1946 (Scincidae).

\section{Collecting Methods and Analyses}

Lizards were collected with an air rifle between December 1995 and December 1998, during the months of October through April, which represent the "wet season" in the area (see ARAÚJO \& HENRIQUES 1984). Collections were restricted to wet season months in order to factor out possible seasonal influences on diet and thermal ecology. Data from a few lizards collected before (May 1995) and after (January 2000) the period cited above were also included to increase sample sizes for analyses of sexual size dimorphism, microhabitat use and reproductive parameters.

Immediately upon collection of each lizard, we recorded its body temperature $\left(\mathrm{T}_{\mathrm{b}}\right)$, the temperature of the air $\left(\mathrm{T}_{\mathrm{a}}\right)$ about $1 \mathrm{~cm}$ above the point the lizard was first seen, and the substrate temperature $\left(\mathrm{T}_{\mathrm{S}}\right)$ on the same point. Temperatures were taken with a fast-reading cloacal thermometer (temperatures were not taken if lizards took more than 30 s to be captured or if they were much too damaged during collection). We also recorded the type of microhabitat each lizard was using when first sighted. Microhabitat types were recorded according to five categories: a) on 
the ground; b) on cactus; c) on bromeliad; d) on shrub; e) on stem or leaf of Guriri palm. For individuals recorded on elevated perches, we measured their height above ground (to the nearest $\mathrm{cm}$ ) with a measuring tape.

In the laboratory, the animals were fixed with $10 \%$ formalin and later stored in $70 \%$ alcohol. The snout-vent length (SVL) of each individual was taken with a digital caliper (to the nearest $0.1 \mathrm{~mm}$ ). The tails of all individuals were examined for signs of regeneration due to previous autotomy. All lizards were then dissected for examination of the gonads and excision of the stomachs. For each female, we recorded its reproductive condition according to stages 1-6 of ROCHA \& VRCIBRADIC (1999): stage 1 - no yolking follicles or oviductal ova; stage 2 - yolking follicles but no oviductal ova; stage 3 - ova or small embryo sacs (less than $4 \mathrm{~mm}$ in diameter) in oviducts; stage 4 - embryo sacs exceeding $4 \mathrm{~mm}$ in diameter, with undeveloped embryos; stage 5 - moderate to well-developed embryos; stage 6 - well formed (near-term or term) foetuses. The size (SVL) of the smallest female with oviductal ova was considered as the minimum size at sexual maturiry for females. For females containing term foetuses [stages 39-40 of DUFAURE \& HUBERT (1961)], we weighed each female prior to removing the embryos, then weighed the embryos (individually), and then divided the total mass of the litter by the mass of the female-plus-litter to estimate the relative clutch mass (RCM), following previous studies (e.g. VITT \& CONGDON 1978; VitT \& PRICE 1982; VITT \& BLACKBURN 1983, 1991); weighting was made using an electronic scale (to the nearest $0.001 \mathrm{~g}$ ). For each male, we took parafin sections of the testes (including the epidydimides) and mounted them on slides (stained with haematoxylin-eosin) to check for the presence of spermatozoa. The size (SVL) of the smallest male with spermatozoa in its testes and/or epidydimides was considered as the minimum size at sexual maturiry for males.

After excision, lizard stomachs were opened and their contents were spread in a Petri dish and examined under a stereomicroscope. Arthropodan prey were identified to the taxonomic level of Order. For each food item found we measured its length and width with a digital caliper (to the nearest $0.1 \mathrm{~mm}$ ) and calculated its volume using the formula for an ovoid spheroid: $V=4 / 3 \pi($ length $/ 2)(\text { width } / 2)^{2}(e . g$. VITT 1991). Mean prey size was calculated as the average length of the five largest identifiable prey items (or of all prey items, for individuals containing five or less items in the stomach).

We tested for size (SVL) differences between male and female $M$. agilis using one-way analysis of variance (ANOVA), considering only the larger $50 \%$ of the animals for each sex (see RAMÍREZ-BAUTISTA et al. 2000). Differences between sexes in the frequency of regenerated tails were tested using the Z-test for proportions (animals whose tails had been broken and lost during captures were ignored). The differences in $\mathrm{T}_{\mathrm{b}}$ and $\mathrm{T}_{\mathrm{a}}$ and in mean prey length between males and females were tested by one-way ANOVA. The relationship between lizard $\mathrm{T}_{\mathrm{b}}$ and $\mathrm{T}_{\mathrm{s}}$ was assessed using Simple Regression Analysis. Simple Regression Analysis was also used to relate litter size to lizard SVL and to relate mean prey length and prey number to lizard SVL (in the latter case, all variables were previously log-transformed). Descriptive statistics are presented throughout the text as arithmetic mean \pm one standard deviation.

Revta bras. Zool. 19 (Supl. 2): $19-29,2002$ 


\section{RESULTS}

Most of the lizards were first sighted on the ground, with $33.8 \%$ of them being found on elevated perches; for those, cacti were the most frequently used microhabitat type (Fig. 1). Mean perch height for lizards found above the ground was $14.8 \pm 7.0 \mathrm{~cm}$ (range $5-30 \mathrm{~cm} ; \mathrm{N}=23$ ).

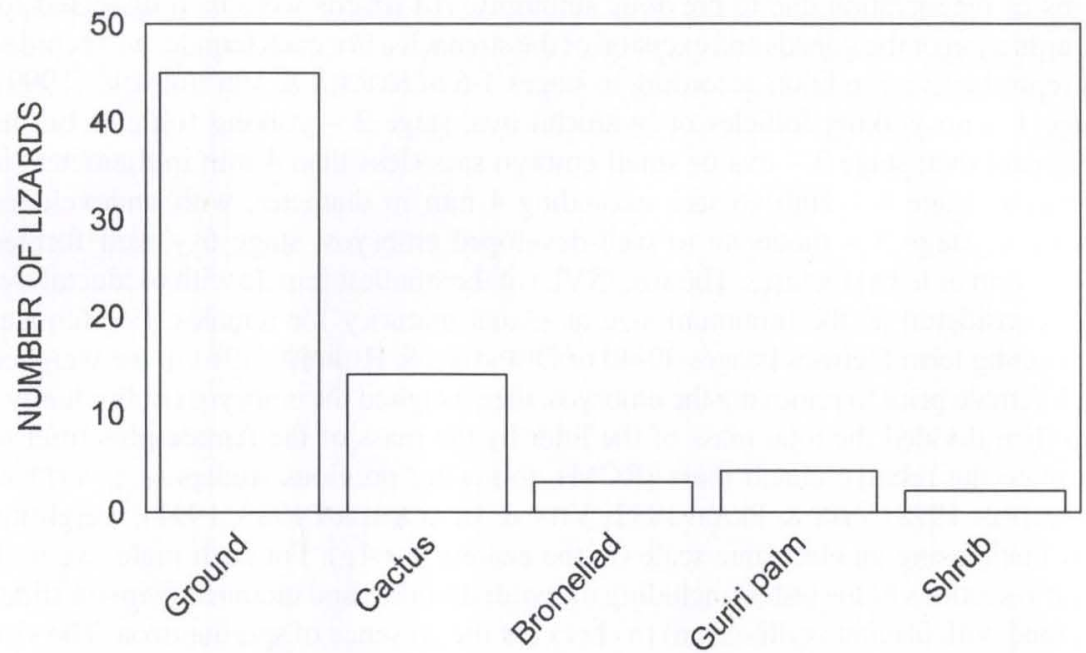

Fig. 1. Frequency of utilization of different microhabitat types by Mabuya agilis at the restinga habitat of Grumari, Rio de Janeiro, Brazil.

Mean $\mathrm{T}_{\mathrm{b}}$ for $M$. agilis was $33.1 \pm 2.4^{\circ} \mathrm{C}$ (range $26.8-37.2^{\circ} \mathrm{C} ; \mathrm{N}=50$ ), whereas mean $\mathrm{T}_{\mathrm{a}}$ was $29.9 \pm 2.8^{\circ} \mathrm{C}$ (range $24.0-36.6^{\circ} \mathrm{C} ; \mathrm{N}=50$ ) and mean $\mathrm{T}_{\mathrm{S}}$ was $29.7 \pm$ $3.2^{\circ} \mathrm{C}$ (range $23.0-34.0^{\circ} \mathrm{C} ; \mathrm{N}=13$ ). Males and females did not differ in $\mathrm{T}_{\mathrm{b}}$ (ANOVA, $\left.\mathrm{F}_{1,48}=1.29, \mathrm{p}=0.26\right)$ nor in $\mathrm{T}_{\mathrm{a}}\left(\mathrm{ANOVA}, \mathrm{F}_{1,48}=0.04, \mathrm{p}=0.84\right)$. Lizard $\mathrm{T}_{\mathrm{b}}$ was positively and significantly related to $T_{a}(R=0.58, p<0.001 ; N=50)$ but not to $T_{s}$ $(\mathrm{R}=0.28, \mathrm{p}=0.36 ; \mathrm{N}=13)$.

The largest $50 \%$ of the females averaged $73.5 \pm 4.4 \mathrm{~mm}$ in SVL (range $65.8-80.0 \mathrm{~mm} ; \mathrm{N}=19)$ and the largest $50 \%$ of the males averaged $68.5 \pm 3.1 \mathrm{~mm}$ in SVL (range 64.5-73.8 $\mathrm{mm} ; \mathrm{N}=16$ ). The two groups differed significantly in $\mathrm{SVL}$ (ANOVA, $\mathrm{F}_{1,33}=14.74, \mathrm{p}=0.001$ ). The frequency of regenerated tails was $83.3 \%$ $(45 / 54)$ for the total sample, and did not differ between males (21/25) and females (24/29) (Z-test, $\mathrm{Z}=-0.12, \mathrm{p}=0.45)$.

The smallest individual in our sample (collected in December 1998) measured $32 \mathrm{~mm} \mathrm{SVL}$ (mass $0.55 \mathrm{~g}$ ), which is similar to the size of the largest foetuses taken from gravid females. Neonate-sized individuals $(32-37 \mathrm{~mm} \mathrm{SVL})$ were collected in the months of December, January and March. The smallest female with implanted ova in the oviducts measured $49 \mathrm{~mm} \mathrm{SVL}$. Another female of about the same size $(49.5 \mathrm{~mm})$ was apparently still immature (stage 1$)$. Of the ten females 
containing fully developed embryos (stage 6), nine were collected in December (1996 and 1998; no adult females were collected on December 1997) and one in January 2000 (Tab. I). The smallest female with fully developed embryos measured $63.1 \mathrm{~mm}$ in SVL. Brood size averaged $3.2 \pm 1.0$ (range 1-5; $\mathrm{N}=21$ ) and was positively and significantly related to female SVL (Fig. 2). Mean RCM was 0.250 \pm 0.042 (range $0.192-0.320 ; \mathrm{N}=7$ ). The smallest male with spermatozoa in the testes/epidydimes measured $46.5 \mathrm{~mm} \mathrm{SVL}$; no spermatozoa were present in a slightly smaller $(45.5 \mathrm{~mm})$ and in a slightly larger $(51 \mathrm{~mm})$ males.

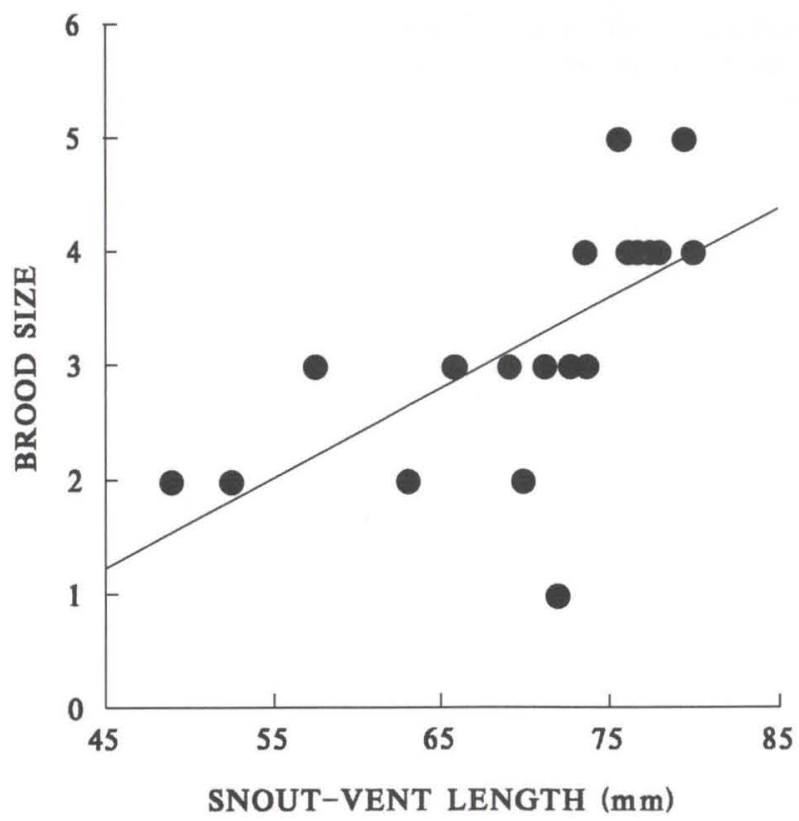

Fig. 2. Relationship between litter size and female SVL $(r=0.65, p=0.001 ; N=21)$ for Mabuya agilis at the restinga habitat of Grumari, Rio de Janeiro, Brazil.

Table I. Number of female Mabuya agilis in each reproductive stage (stages 1-6 of RocHA \& VRCIBRADIC 1999) in each month (pooled data from different years) at the restinga of Grumari, RJ. No females were collected in the month of November.

\begin{tabular}{|c|c|c|c|c|c|c|}
\hline \multirow{2}{*}{ Month } & \multicolumn{6}{|c|}{ Stage } \\
\hline & 1 & 2 & 3 & 4 & 5 & 6 \\
\hline October & & & & & 1 & \\
\hline December & 1 & 2 & 1 & & & 9 \\
\hline January & & 4 & 2 & & & 1 \\
\hline February & & & 1 & & & \\
\hline March & & 1 & 3 & & & \\
\hline April & & & 1 & & & \\
\hline
\end{tabular}


Of the 57 lizards examined for diet analyses, only two (3.5\%) had empty stomachs. The diet of $M$. agilis in Grumari was basically composed of arthropods, with no consumption of plant material (Tab. II). Overall, the most important items in the diet were spiders, lepidopteran larvae and homopterans (Tab. II). Termites were numerically the most important items, though they were not among the most important volumetrically (Tab. II). The stomach of one adult female ( $75.7 \mathrm{~mm} \mathrm{SVL}$ ) contained the remains of a gekkonid lizard (Hemidactylus mabouia). The number of identifiable food items per stomach averaged $5.3 \pm 6.6$ (median $=3$; range 1-37; $\mathrm{N}=54$ ). Mean prey length was $8.5 \pm 6.6 \mathrm{~mm}$ (median $=6.0 \mathrm{~mm}$; range $2.0-29.0$ $\mathrm{mm}, \mathrm{N}=45)$ and did not differ significantly between sexes (t-test; $\mathrm{t}=1.60 ; \mathrm{p}=0$. 12 ; $\mathrm{DF}=43$ ). Since female $M$. agilis grow larger than males, we tested again for intersexual differences in mean prey length through an Analysis of Covariance (ANCOVA) with lizard SVL as covariate, to see if males eat proportionally larger prey than females; again, no difference was found $\left(F_{1,1,42}=2.30 ; p=0.14\right)$. The relationship between mean prey length and lizard SVL was not significant $(\mathrm{r}=0.28$; $\mathrm{p}=0.07 ; \mathrm{N}=45$ ).

\section{DISCUSSION}

The data confirm that $M$. agilis is a typically ground-dwelling skink, with limited climbing abilities. It climbs less frequently and tend to use lower perches than other congeners studied in Brazil (VITT \& BLACKBURN 1991; VRCIBRADIC \& ROCHA 1996, 1998; VITT et al. 1997). This species also seems to be frequently associated with cacti patches: $20.6 \%$ of the individuals collected were perched on cacti when first seen, and several others were collected on the ground within or near cacti patches. Frequent association of $M$. agilis with cacti has been previously reported in other restinga areas (ARAÚJO 1991; VRCIBRADIC \& ROCHA 2002) and may provide the animals with protection from predators as well as with some advantages such as constituting a substrate for thermoregulation (see VRCIBRADIC \& ROCHA 2002).

Mean and maximum body temperatures of active M. agilis from Grumari were similar to those reported for conspecific populations in other restingas (ROCHA \& VRCIBRADIC 1996; HatANO et al. 2001; VRCIBRADIC \& ROCHA 2002). Mean $\mathrm{T}_{\mathrm{b}}$ for $M$. agilis studied by VRCIBRADIC \& ROCHA (1995) at yet another restinga was somewhat lower $\left(31.4^{\circ} \mathrm{C}\right)$, but that study was done during a winter month (July), and some of the data were collected during periods of overcast weather.

The data revealed a significant sexual size dimorphism in $M$. agilis, with females growing larger than males, as found by us (ROCHA \& VRCIBRADIC 1999) in a conspecific population from the restinga of Barra de Maricá (also in the state of Rio de Janeiro). The frequency of regenerated tails in M. agilis was considerable $(83 \%)$, suggesting a high rate of caudal autotomy in this population. High frequencies of regenerated tails (59-83\%) have been previously reported for other congeneric populations in Brazil (VITT 1981; VAN SLUYS et al. 2002) and our findings in the present study support a general tendency of neotropical Mabuya to present high rates of tail breakage. 
Table II. Volume (em $\mathrm{mm}^{3}$ ), number and frequency of occurrence of each food item category in the diet of Mabuya agilis in Grumari, RJ $(N=57)$. Category "Miscellaneous" refer to unidentifiable arthropod fragments.

\begin{tabular}{|c|c|c|c|}
\hline Item & Volume (\%) & Number (\%) & Frequency (\%) \\
\hline \multicolumn{4}{|l|}{ Insecta } \\
\hline Blattaria & $79.20 \quad(0.80)$ & $3(1.1)$ & $3(5.3)$ \\
\hline Coleoptera & $32.50 \quad(0.30)$ & $3(2.1)$ & $5(8.8)$ \\
\hline Diptera & $0.070 \quad(\sim 0)$ & $1(0.4)$. & $1(1.8)$ \\
\hline Hemiptera & $99.70 \quad(0.90)$ & $9(3.2)$ & $6(10.5)$ \\
\hline Homoptera & $1,001.10 \quad(9.50)$ & $16 \quad(5.7)$ & $14(24.6)$ \\
\hline \multicolumn{4}{|l|}{ Hymenoptera } \\
\hline Formicidae & $146.10 \quad(1.40)$ & $14(4.9)$ & $8(14.0)$ \\
\hline Others & $9.30 \quad(0.10)$ & $5(1.8)$ & $4(7.0)$ \\
\hline Isoptera & $306.70 \quad(2.90)$ & $107(37.8)$ & $10(17.5)$ \\
\hline Lepidoptera & $154.00 \quad(1.50)$ & $1(0.4)$ & $1(1.8)$ \\
\hline Mantodea & $59.30 \quad(0.60)$ & $2(0.7)$ & $2(3.5)$ \\
\hline Odonata & $188.50 \quad(1.80)$ & $1(0.4)$ & $1(1.8)$ \\
\hline Orthoptera & $2,228.30(21.20)$ & $11(3.9)$ & $9(15.8)$ \\
\hline Psocoptera & $3.10 \quad(0.03)$ & $1(0.4)$ & $1(1.8)$ \\
\hline \multicolumn{4}{|l|}{ Larvae } \\
\hline Coleoptera & $9.10 \quad(0.10)$ & $2(0.7)$ & $1(1.8)$ \\
\hline Diptera & $337.40 \quad(3.20)$ & $2(0.7)$ & $2(3.5)$ \\
\hline Lepidoptera & $1,911.60(18.20)$ & $24(8.5)$ & $14(24.6)$ \\
\hline Neuroptera & $36.10 \quad(0.30)$ & $1 \quad(0.4)$ & $1(1.8)$ \\
\hline Pupae & $635.80 \quad(6.00)$ & $3(1.1)$ & $3(5.3)$ \\
\hline \multicolumn{4}{|l|}{ Arachnida } \\
\hline Acarina & $1.30 \quad(0.01)$ & $1(0.4)$ & $1(1.8)$ \\
\hline Aranae & $782.80 \quad(7.40)$ & $51(18.0)$ & $29(50.9)$ \\
\hline Opilionida & $13.10 \quad(0.10)$ & $1(0.4)$ & $1(1.8)$ \\
\hline Pseudoscorpionida & $2.70 \quad(0.03)$ & $2(0.7)$ & $1(1.8)$ \\
\hline Scorpionida & $476.20 \quad(4.50)$ & $1(0.4)$ & $1(1.8)$ \\
\hline Chilopoda & $6.50 \quad(0.06)$ & $1(0.4)$ & $1(1.8)$ \\
\hline Diplopoda & $1.70 \quad(0.02)$ & $2(0.7)$ & $1(1.8)$ \\
\hline \multicolumn{4}{|l|}{ Crustacea } \\
\hline Amphipoda & $25.50 \quad(0.20)$ & $3(1.1)$ & $1(1.8)$ \\
\hline Isopoda & $151.80 \quad(1.40)$ & $10(3.5)$ & $9(15.8)$ \\
\hline \multicolumn{4}{|l|}{ Mollusca } \\
\hline Gastropoda & $1.60 \quad(0.02)$ & $1(0.4)$ & $1(1.8)$ \\
\hline \multicolumn{4}{|l|}{ Vertebrata } \\
\hline Hemidactylus mabouia & $38.90 \quad(0.40)$ & $1(0.4)$ & $1(1.8)$ \\
\hline Mabuya shed skin & $43.90 \quad(0.40)$ & - & $2(3.5)$ \\
\hline Miscellaneous & $1,726.00(16.40)$ & & \\
\hline Total & $10,513.40$ & 283 & 57 \\
\hline
\end{tabular}

Brood size and minimum size at maturity for female $M$. agilis in Grumari were coincident with those of the conspecific population of Barra de Maricá (ROCHA \& VRCIBRADIC 1999). However, the significant relationship between brood size and female SVL found in Grumari was not found in that previous study, in which a slightly smaller sample size was used. The size of the smallest reproductive male found in the present study was smaller $(47 \mathrm{~mm})$ than that reported by us $(55 \mathrm{~mm})$ for a conspecific population at the Barra de Maricá restinga (ROCHA \& VRCIBRADIC 1999) and slightly larger than that (41 mm) reported by VITT \& BLACKBURN (1983) for a similar-sized congener, $M$. heathi Schmidt \& Inger, 1951, at a caatinga site in 
northeastern Brazil. ROCHA \& VRCIBRADIC (1999) pointed out that the size of 55 $\mathrm{mm}$ may not represent the actual minimum reproductive size for males, since no males smaller than that were examined in that study. Here we present evidence that males of $M$. agilis actually reach reproductive maturity at SVLs smaller than 50 $\mathrm{mm}$, as in $M$. heathi.

The mean RCM value for $M$. agilis (0.250) was lower than those reported for the three other Brazilian congeners for which RCM data is available, namely $M$. heathi (0.326; VITT \& BLACKBURN 1983), M. nigropunctata (Spix, 1824) [= M. bistriata (Spix, 1824)] (0.362; VITT \& BLACKBURN 1991) and M. agmosticha Rodrigues, 2000 (= Mabuya sp.) (0.348; STEVAuX 1993). In the first two species, the higher RCM values probably reflect the fact that those species have larger broods (about five young per litter, on average) than M. agilis. On the other hand, $M$. agmosticha has even smaller litters, on average, than M. agilis. In that case, however, the high RCM values were probably influenced by the fact that STEVAUX (1993) used the mass of the females without tails as the denominator of the RCM index, since the tail may represent a significant percentage of the total body mass in species of Mabuya (e.g. $19.3 \%$ in M. heathi; VITT 1981). Finally, it is important to add here that other factors such as escape behavior and foraging mode may also be associated with RCM (VITT \& CONGDON 1978; VITT \& PRICE 1982), but since M. agilis does not appear to differ in such traits from other Brazilian congeners (VRCIBRADIC \& ROCHA 1996; pers. obs.), we do not believe that they may be influencing the low RCM of that species.

The parturition period of M. agilis in Grumari apparently extends to early January, though our lack of data for the months of October and November precludes our estimation of when it starts. ROCHA \& VRCIBRADIC (1999) estimated the parturition period of M. agilis in Barra de Maricá to peak during October-November, though the scarcity of data from November through February did not allow an estimation of when it actually ceases. If we combine the results of that study with those of the present one, we have a parturition period estimate for this species that extends from late September to early January. Nevertheless, we should not rule out the possibility that the parturition period may not be exactly coincident between those two populations, even though the two localities are only some $160 \mathrm{~km}$ apart and located at about the same latitude and altitude.

As in other Brazilian Mabuya populations previously studied (VITT \& BLACKBURN 1991; VITT et al. 1997; VRCIBRADIC \& ROCHA 1998), M. agilis in Grumari feeds basically on arthropods, with no consumption of plant material. However, in another conspecific population previously studied by us at the restinga of Barra de Maricá (also in Rio de Janeiro state), we recorded consumption of fruits by some individuals (VRCIBRADIC \& ROCHA 1996), which indicates that this skink may sometimes opportunistically exploit non-animal food sources when they are available. Also, one individual from Grumari was found to have consumed a small gekkonid lizard (Hemidactylus mabouia), and young individuals of two other lizard species have previously been reported as prey of M. agilis in other restinga areas (VRCIBRADIC \& ROCHA 1995, 1996). This suggests that opportunistic predation on small vertebrates may also not be uncommon in this skink species. 
The low proportion of individuals of $M$. agilis with empty stomachs agrees with the general pattern for skinks as observed by HUEY et al. (2001): those authors found generally low percentages of empty stomachs among samples of several species of scincid lizards from three continents. The mean number of prey per stomach and mean prey length of $M$. agilis from Grumari were similar to those observed for other Brazilian populations of congeners (VITT 1991; VITT \& BLACKBURN 1991; ViTT et al. 1997; VITT \& ZANI 1998). Thus, it seems that neotropical Mabuya tend to eat a small number of prey at a time and usually ingest items that are neither too large nor too small (relative to their size), though comparatively large items are occasionally consumed. It is also worth noting that the most important items (considering frequency of occurrence, number, and volume as a whole) in the diet of $M$. agilis were all soft-bodied prey (i.e. spiders, insect larvae, homopterans, isopterans and orthopterans). Consuming prey that are both relatively large and soft-bodied may be energetically advantageous (if such prey are not locally rare), since the benefits of energy gain are maximized and the costs of food processing are minimized.

The results of our work confirm and expand the knowledge of ecological tendencies previously observed for $M$. agilis in other areas. This species may thus be characterized as a ground-dwelling, early maturing skink with low RCM and relatively small broods (compared to other congeners; but see ROCHA et al. 2002b), which feeds on a wide variety of prey types, but predominantly on relatively large and soft-bodied arthropods.

\begin{abstract}
ACKNOWLEDGEMENTS. This study is a portion of the results of the "Programa de Ecologia, Conservação e Manejo de Ecossistemas do Sudeste Brasileiro" and of the Eastern Brazilian Vertebrate Ecology Project, both of the Setor de Ecologia, Instituto de Biologia, Universidade do Estado do Rio de Janeiro. We thank P.F. Teixeira-Filho, M. Cunha Barros, H.L.T. Zaluar and L.C. Prado for their help during fieldwork. The first author benefitted from a graduate fellowship (Process 143607/ 98-7 NV) and the second author from research grants (Processes 300819/94-3 NV and 461970/00-7 APQ), all given by the Conselho Nacional do Desenvolvimento Cientifico e Tecnológico (CNPq). This study was also partially supported by a grant from the Fundação de Amparo à Pesquisa do Estado do Rio de Janeiro - FAPERJ (Process E-26/170.385/97). Field collections of lizards were made under permit of the Instituto Brasileiro do Meio Ambiente e Recursos Naturais Renovéveis - IBAMA (Process 03486/99-85).
\end{abstract}

\title{
REFERENCES
}

ARAújo, A.F.B. 1991. Structure of a white sand-dune lizard community of coastal Brazil. Rev. Brasil. Biol. 51: 857-865.

Araújo, D.S.D. \& R.P.B. Henriques. 1984. Análise florística das restingas do Rio de Janeiro, p. 159-193. In: L.D. Lacerda; D.S.D. Araújo; R. Cerqueira \& B. Turcq. (Eds.). Restingas: Origem, Estrutura, Processos. Niterói, Centro Editorial UFF, 475p.

Dufaure, J.P. \& J. Hubert. 1961. Table de developpement de lézard vivipare, Lacerta (Zootoca) vivipara Jacquin. Arch. Anat. Microscop. Morphol. Exp. 50: 309-328.

Eiten, G. 1992. Natural Brazilian vegetation types and their causes. An. Acad. Bras. Ciênc. 64 (Suppl. 1): 35-65. 
Hatano, F.H.; D. VRcibradic; C.A.B. Galdino; M. Cunha-Barros; C.F.D. Rocha \& M. van Sluys. 2001. Thermal ecology and activity patterns of the lizard community of the restinga of Jurubatiba, Macaé, RJ. Rev. Brasil. Biol. 61: 287-294.

HUEY, R.B.; E.R. PIANKa \& L.J. VitT. 2001. How often do lizards "run on empty"? Ecology 82: 1-7.

PIANKA, E.R. 1970. Comparative autecology of the lizard Cnemidophorus tigris in different parts of its geographic range. Ecology 51: 703-720.

RamíreZ-Bautista, A.; C. BALDERAS-VALdivia \& L.J. Vitt. 2000. Reproductive ecology of the whiptail lizard Cnemidophorus lineatissimus (Squamata: Teiidae) in a tropical dry forest. Copeia 2000: $712-722$.

ROCHA, C.F.D. 1994. Introdução à ecologia de lagartos brasileiros, p. 39-57. In: A.T. BERnARDES; L.B Nascimento \& G.A. Cotta (Eds). Herpetologia do Brasil. I. Belo Horizonte, Pontifícia Universidade Católica de Minas Gerais, 134p.

2000. Biogeografia de répteis de restingas: distribuição, ocorrência e endemismos, p. 99-116. In: F.A. Esteves \& L.D. LACERDA (Eds). Ecologia de Restingas e Lagoas Costeiras. Macaé, NUPEM/UFRJ, 394p.

ROCHA, C.F.D. \& H.G. BERGaLLO. 1997. Intercommunity variation in the distribution of abundance of dominant lizard species in restinga habitats. Ci. Cult. 49: 269-274.

Rocha, C.F.D. \& D. VRCibradic. 1996. Thermal biology of two sympatric skinks (Mabuya macrorhyncha and Mabuya agilis) in a Brazilian restinga habitat. Austr. Jour. Ecol. 21: 110-113.

- 1999. Reproductive traits of two sympatric viviparous skinks (Mabuya macrorhyncha and Mabuya agilis) in a Brazilian restinga habitat. Herpetol. Jour. 9: 43-53.

ROCHA, C.F.D.; D. VRCIBRADIC \& A.F.B. ARAújo. 2000. Ecofisiologia de répteis de restingas brasileiras, p. 117-149. In: F.A. Esteves \& L.D. LACERDA (Eds). Ecologia de Restingas e Lagoas Costeiras. Macaé, NUPEM/UFRJ, 394p.

Rocha, C.F.D.; G.F. Dutra; D. VRCibradic \& V.A. MEnEzEs. 2002a. The terrestrial reptile fauna of the Abrolhos archipelago: species list and ecological aspects. Braz. Jour. Biol. 62: 285-291.

Rocha, C.F.D.; D. VRCibradic; R.L. TeiXeIRA \& M.G.T. CuzZuol. 2002b. Interpopulational variation in litter size of the skink Mabuya agilis in southeastern Brazil. Copeia 2002: 857-864.

StevauX, M.N. 1993. Estratégia reprodutiva de Mabuya sp. (Sauria: Scincidae): um padrão geral de reprodução para o gênero na região neotropical. Rev. Nordestina Biol., João Pessoa, 8: 61-86.

Suguro, T. \& M.G. Tessler. 1984. Planícies de cordões litorâneos quaternários do Brasil, p.15-25. In: L.D. Lacerda; D.S.D. Araujo; R. Cerqueira \& B. TurcQ (Eds). Restingas: Origem, Estrutura, Processos. Niterói, Centro Editorial da Univ. Federal Fluminense, 475p.

VAn Sluys, M.; D. VRCibradic \& C.F.D. Rocha. 2002. Tail loss in the syntopic lizards Tropidurus itambere (Tropiduridae) and Mabuya frenata (Scincidae) in southeastern Brazil. Stud. Neotrop. Fauna Environ. 37: 227-231.

VANZOLINI, P.E. 1988. Distributional patterns of South American lizards, p. 317-342. In: P.E. VANZOLINI \& W.R. Heyer (Eds). Proceedings of a Workshop on Neotropical Distribution Patterns. Rio de Janeiro, Academia Brasileira de Ciências.

VITT, L.J. 1981. Tail autotomy and regeneration in the tropical skink, Mabuya heathi. Jour. Herpetol. 15: 454-457.

- 1991. An introduction to the ecology of Cerrado lizards. Jour. Herpetol. 25: 79-90.

VITT, L.J. \& J.D. ConGDON. 1978. Body shape, reproductive effort, and relative clutch mass in lizards: resolution of a paradox. Amer. Nat. 112: 595-608.

VITT, L.J. \& H.J. PRICE. 1982. Ecological and evolutionary determinants of relative clutch mass in lizards. Herpetologica 38: 237-255.

VITT, L.J. \& D.G. BlackBuRn. 1983. Reproduction in the lizard Mabuya heathi (Scincidae): a commentary on viviparity in new world Mabuya. Can. Jour. Zool. 61: 2798-2806.

1991. Ecology and life history of the viviparous lizard Mabuya bistriata (Scincidae) in the Brazilian Amazon. Copeia 1991: 918-927.

VITT, L.J. \& G.R. CoLli. 1994. Geographical ecology of a neotropical lizard: Ameiva ameiva (Teiidae) 
in Brazil. Can. Jour. Zool. 72: 1986-2008.

VITT, L.J. \& P.A. ZANI. 1998. Ecological relationships among sympatric lizards in a transitional forest in the Amazon of Brazil. Jour. Trop. Ecol. 14: 63-86.

VITT, L.J., P.A. ZANI \& A.C. MARINHO-LimA. 1997. Heliotherms in tropical rain forest: the ecology of Kentropyx calcarata (Teiidae) and Mabuya nigropunctata (Scincidae) in the Curuá-Una of Brazil. Jour. Trop. Ecol. 13: 199-220.

VRCIBRADIC, D. \& C.F.D. Rocha. 1995. Ecological observations on the scincid lizard Mabuya agilis in a Brazilian restinga habitat. Herpetol. Rev. 26: 129-131.

- 1996. Ecological differences in tropical sympatric skinks (Mabuya macrorhyncha and Mabuya agilis) in southeastern Brazil. Jour. Herpetol. 30: 60-67.

1998. Ecology of the Skink Mabuya frenata in an area of rock outcrops in southeastern Brazil. Jour. Herpetol. 32: 229-237.

2002. Use of cacti as heat sources by thermoregulating Mabuya agilis (Raddi) and Mabuya macrorhyncha Hoge (Lacertilia, Scincidae) in southeastern Brazil. Revta bras. Zool. 19: 77-83.

Received in 12.VII.2002; accepted in 05.XI.2002. 